\title{
AOR
}

Selected Papers of \#AolR2021:

The 22nd Annual Conference of the

Association of Internet Researchers

Virtual Event / 13-16 Oct 2021

\section{THE MERGING OF MUSIC CRITICISM AND MUSIC PROMOTION: CONVERGED MUSIC PROFESSIONALS ON FACEBOOK}

Madis Järvekülg

Baltic Film, Media and Arts School, Tallinn University

The digitalization of information and cultural production has undermined the business models of legacy media companies as well as music firms. This paper is particularly interested in the transformations in music journalism and its potential to transfer in some form to the digital media sphere. Music journalism, indeed, represents the intersection of two industries that both have undergone a 'free fall, with no bottom in sight' (McLeese, 2010: 433).

Firstly, the decrease in readership and advertising revenues, intensified by the fragmentation of online audiences, have led to the 'commercialization' of cultural journalism in general - its submission to market requirements (Verboord and Janssen, 2015: 831). Relatedly, scholars have indicated the decline of the 'authority' of cultural journalists and critics more broadly (Kristensen, Haastrup and Holdgaard, 2018) and the 'industrialization' of music criticism more specifically (Conner and Jones, 2014). This has consequences for the identities, roles, functions of music critics who were once understood as 'autonomous gatekeepers' and 'opinion leaders' (Hirsch, 1972).

Secondly, the music industry was the first creative sector that was thoroughly disrupted by digital technologies. While optimistic scholars have seen the 'democratizing' potential of this shift, scholars informed by the critical political economy have referred to the continuation and expansion of the traditional power inequalities in the music industries. In the oversaturated marketplace dominated by streaming services such as Spotify, industry power 'remains tied to access to capital, financing, and marketing support' (Hesmondhalgh and Meier, 2015: 103). Competition for the limited amount of attention from audiences has made the music industries indistinguishable from 'promotional industries' (Meier, 2019).

As most of the recent music-related media studies have focused on streaming services, the contemporary role of legacy media as well as social media platforms - either as platforms for music promotion or discussion - has received hardly any scholarly attention. Therefore, the present study asks: How do music critics and music

Suggested Citation (APA): Järvekülg, M. (2021, October). The Merging of Music Criticism and Music Promotion: Converged Music Professionals on Facebook. Paper (or panel) presented at AolR 2021: The 22nd Annual Conference of the Association of Internet Researchers. Virtual Event: AolR. Retrieved from http://spir.aoir.org. 
entrepreneurs in Estonia make use of Facebook? How does it transform our understanding of and the relationships between music criticism and music promotion?

\section{Methodological practicalities}

This paper is based on the analysis of 32 semi-structured interviews with Estonian music critics/journalists, experts, and entrepreneurs. The interviews were conducted between November 2018 and February 2020 and focused on how the participants make use of Facebook concerning their professional identities; what are the roles through which they engage in local music cultures; how does the platform encourage or discourage them to present these roles; and how does it shape their status and relationship with other players in the local music sphere. Early in the interviews, it became clear that, among all digital platforms, Facebook provides the most diverse set of engagement practices. Simultaneously with interviews and informed by them, ethnographic observations on Facebook were conducted which provided contextual insight for the meaningful analysis of interview data.

The constructivist grounded theory approach as introduced by Charmaz (2006) was applied to the interview transcripts. Qualitative data analysis software NVivo was used for coding the interviews.

\section{Findings}

Firstly, the interviews revealed that a number of participants were engaged with local music cultures from a variety of different positions. In many cases, the various roles adopted by one participant were further multiplied on Facebook, as they held administrative control over various fan pages and groups. Some participants, for example, managed more than 10 pages: pages of a record label, radio show, weekly publication, concert series, etc.

Among music critics, I distinguished three stances adopted on Facebook: the converged promoter, the calculating professional, and the autonomous critic (Järvekülg, accepted for publication). The position of the converged promoter means cross-sharing and publicly promoting all kinds of content - either record reviews, label news, event invitations, etc. - making use of numerous pages controlled by the critic. While this compromises the sense of critical distance and autonomy of a critic, it also provides greater visibility of one's converged identities combined into a digital personality. Adopting the position of the autonomous critic, however, means avoiding social media use other than for personal concerns and holding on to the decreasing musical authority acquired through legacy media, resulting in low visibility. The position of the calculating professional refers to the increasingly hesitant professional identities of music critics regarding negotiations between public and private, personal and professional.

Among the participants primarily identified as music entrepreneurs, two sets of promotional approaches were distinguished: brand-centered and community-oriented (Järvekülg and Wikström, 2021). As brand-centered entrepreneurs are characterized by a strong distinction between one's personal and professional sphere, they are only engaging with Facebook through the main brands organized as Facebook pages 
directly associated with their business. The community-oriented approaches, however, are characterized by a network of promotional nodes - taste-specific groups, numerous pages, personal profile - that can be converged and used for synchronized promotion to cultivate and mobilize niche audiences. The latter approaches are the basis of what I call promotional gatekeeping, as it enables to build cultural authority and prestige among particular genre cultures.

Altogether, I argue that the autonomy and independence once associated with the authority of music critics and journalists have died out in the context of Facebook and highly fragmented music cultures. Music criticism and music promotion have become almost indistinguishable, as some niche music entrepreneurs have acquired expert authority as promotional gatekeepers and music critics tend to turn into converged promoters. Both trends illustrate the decreasing distance between music criticism and music promotion.

This paper is based on two research articles (Järvekülg, accepted for publication; Järvekülg and Wikström, 2021) that are part of a PhD dissertation titled 'Facebook as a digital music platform: Communicative reorganization of Estonian music cultures'.

\section{References}

Charmaz, K. (2006). Constructing Grounded Theory: A Practical Guide Through Qualitative Analysis. London: SAGE.

Conner, T. and Jones, S. (2014). Art to Commerce: The Trajectory of Popular Music Criticism. IASPM@Journal, 4(2), 7-23.

Hesmondhalgh, D., and Meier, L. (2015). Popular music, independence and the concept of the alternative in contemporary capitalism. In: Bennett, J. and Strange, N. (eds)

Media Independence: Working with Freedom or Working for Free? New York:

Routledge, pp. 94-116.

Hirsch, P. (1972). Processing fads and fashions: An organization-set analysis of cultural industry systems. American Journal of Sociology, 77(4), 639-659.

Järvekülg, M., and Wikström, P. (2021). The emergence of promotional gatekeeping and converged local music professionals on social media. Convergence. Doi: https://doi.org/10.1177/13548565211032376

Järvekülg, M. (accepted for publication). The Converged Promoter, the Calculating Professional, and the Autonomous Critic - the presentation of Musical Authority on Social Media. Popular Communication.

Kristensen, N., Haastrup, H., and Holdgaard, N. (2018). Cultural Critique: Renegotiating Cultural Authority in Digital Media Culture. MedieKultur, 34(65), 3-9.

McLeese, D. (2010). Straddling the Cultural Chasm: The Great Divide between Music Criticism and Popular Consumption. Popular Music and Society, 33(4), 433-447. 
Meier L (2019). Popular music, streaming, and promotional media: Enduring and emerging industrial logics. In: Deuze, M. and Prenger, M. (eds) Making Media:

Production, Practices, and Professions. Amsterdam: Amsterdam University Press, pp. 321-334.

Verboord, M. and Janssen, S. (2015). Arts Journalism And Its Packaging In France, Germany, The Netherlands And The United States, 1955-2005. Journalism Practice, 9(6), 829-852. 